\title{
Surface Water-Quality Activities of the U.S. Geological Survey in New England
}

The U.S. Geological Survey (USGS) collaborates with a variety of Federal, State, local, and tribal partners on scientific projects to provide reliable and impartial water-quality data and interpretation to resource managers, planners, stakeholders, and the general public. The themes related to surface water quality include the following:

- Water quality monitoring networks

- Effects of best management practices (BMPs) and low impact development (LID) on water quality

- Load estimation techniques and total maximum daily load assistance

- Mercury studies

- Toxics and emerging contaminants

- Eutrophication and nuisance algal blooms

\section{Water-Quality Monitoring Network}

The USGS operates ambient surface water-quality monitoring networks locally and statewide in association with long- and short-term projects for a variety of field parameters (for example, $\mathrm{pH}$, dissolved oxygen, specific conductance, and temperature) and chemical constituents (for example, nutrients and contaminants). The USGS has maintained long-term water-quality networks measuring multiple constituents in Connecticut and Rhode Island. Nutrients, major ions, trace elements, total organic carbon, and indicator bacteria have been monitored at multiple sites in Connecticut since 1973. Specific conductance, $\mathrm{pH}$, dissolved oxygen, nutrients, major ions, trace elements, total organic carbon, and indicator bacteria have been monitored at multiple sites in Rhode Island since the mid-1970s. The USGS is well positioned to provide the most recent statistical trend techniques to analyze long-term trends in water-quality data.

\section{National Water-Quality Assessment Program}

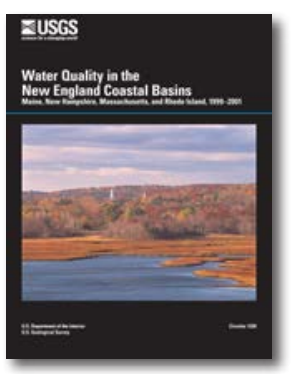

The USGS National WaterQuality Assessment Program Project (http://nh.water.usgs.gov/projects/nawqa/ design2.htm) has evolved over time and currently [2016] samples at stations in the Connecticut, Green, and Norwalk Rivers. An intensive study from 1999 to 2001 related water-quality status to extent of urbanization in an assessment of macroinvertebrate species abundance, concentrations of toxic trace metals, and occurrence of persistent organic chemicals, such as dichlorodiphenyltrichloroethane, chlordane, polychlorinated biphenyls (PCBs), and polycyclic aromatic hydrocarbons in streambed sediments. Publication at https://pubs.er.usgs.gov/ publication/cir1226.

\section{Water-Quality Trends During the 20th Century}

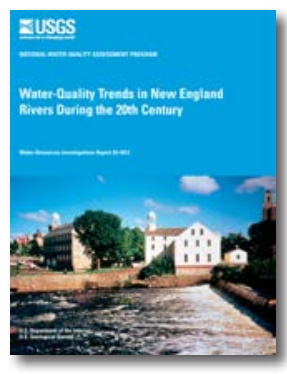

Water-quality data from the Blackstone, Connecticut, and Merrimack Rivers during parts of the 20th century were examined for trends in concentrations of sulfate, chloride, residue upon evaporation, nitrate, and total phosphorus. Publication at https://pubs.er.usgs.gov/publication/ wri034012.

Water-Quality Trends in the Scituate Reservoir, Rhode Island

Water-quality and streamflow data collected at 37 surface-water monitoring stations in the Scituate Reservoir drainage area in Rhode Island from 1988 through 2012 were analyzed to determine the status and trends in selected water-quality constituents. Publication at http://dx.doi.org/10.3133/sir20155058

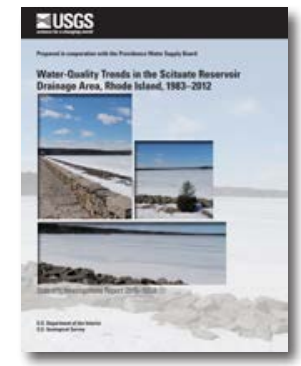

Nitrogen and Phosphorus Trends in Lake Champlain, Vermont

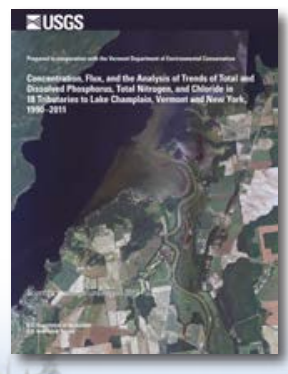

In cooperation with the Vermont Department of Environmental Conservation, the USGS evaluated status and trends of nitrogen and phosphorus concentrations and loads in 18 tributaries to Lake Champlain. Categories of basin characteristics that were examined included physical and demographic properties, point sources of phosphorus, land use, and BMPs. Publication at https://pubs.er.usgs.gov/ publication/sir20135021. 


\section{Evaluating Effects of BMPs and LID on Water Quality}

The USGS cooperates with the Federal Highway Administration and various State agencies in New England to evaluate the effectiveness of BMPs and LID on water quality. The USGS provides the capability for frequent collection of water-quality samples under a variety of complex land-use, topographic, and climatic conditions.

\section{Water-Quality Along the Southeast Expressway in Boston, Massachusetts}

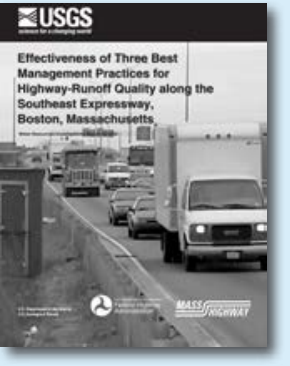

In cooperation with the Federal Highway Administration and the Massachusetts Highway Department, the USGS conducted a study to determine the effectiveness of three BMPs in reducing suspended-sediment loads and related constituents along the Southeast Expressway in Boston. The BMPs included a single catch basin, three 1,500-gallon oil-grit separators, and mechanical street sweeping. Publication at https://pubs.er.usgs.gov/ publication/wri024059.

\section{BMPs To Improve Water Quality in Urban Vermont}

In cooperation with the Vermont Department of Environmental Conservation, the USGS collected data from 2000 through 2010 on streamflow and concentrations of phosphorus and suspended sediment in Englesby Brook in Burlington, Vt., to investigate the effectiveness of urban BMPs in improving water quality in a small urban stream. Publication at https://pubs.er.usgs.gov/ publication/sir20125103.

\section{LID and Water Demand Reduction in} the Ipswich River Basin, Massachusetts
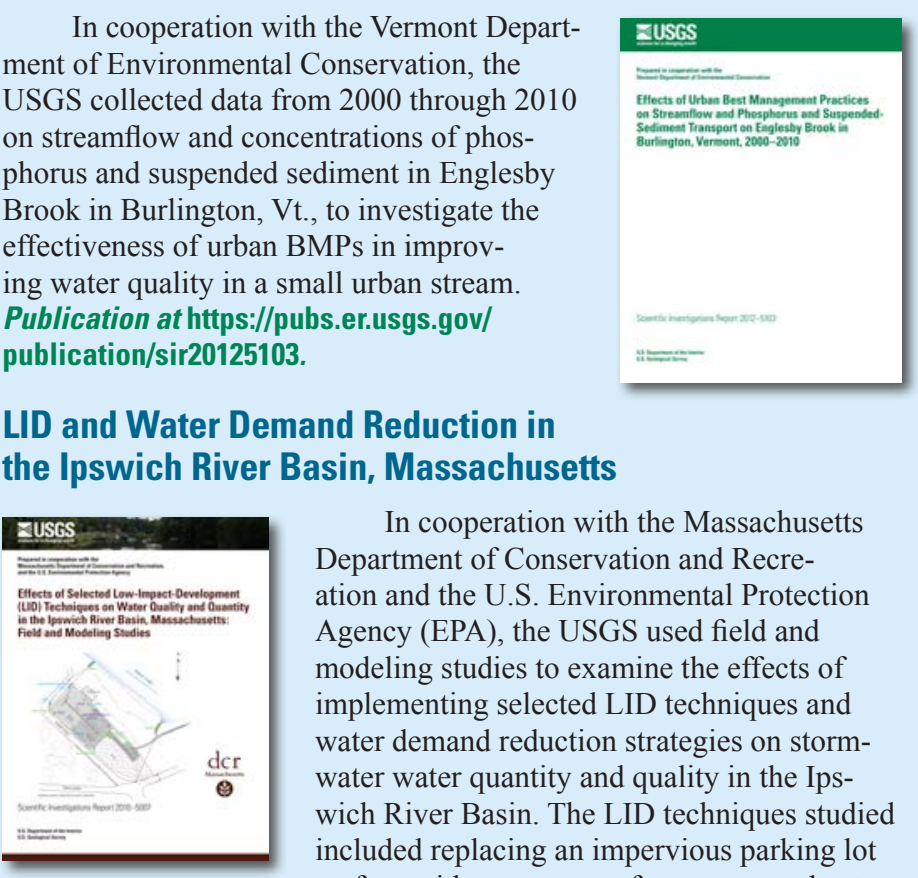

In cooperation with the Massachusetts Department of Conservation and Recreation and the U.S. Environmental Protection Agency (EPA), the USGS used field and modeling studies to examine the effects of implementing selected LID techniques and water demand reduction strategies on stormwater water quantity and quality in the Ipswich River Basin. The LID techniques studied included replacing an impervious parking lot surface with a porous surface on groundwater quality, installing rain gardens and porous pavement, and installing a 3,000-square-foot green roof. Publication at https://pubs.er.usgs.gov/ publication/sir20105007.

\section{Effects of Sewering on Nitrogen Loads in the Niantic River Estuary, Connecticut}

In cooperation with the Connecticut Department of Energy and Environmental Protection (CTDEEP), the USGS conducted a study to evaluate the effects of sewering on concentration and loads of nitrogen to adjacent surface waters on the Niantic River Estuary in southeastern Connecticut. Publication at http://dx.doi.org/10.3133/sir20155011.

\section{Load Estimation Techniques and Total Maximum Daily Load Assistance}

The USGS cooperates with State agencies in New England to estimate total maximum daily loads for nitrogen and phosphorus for temporal trend analysis and identification of nutrient sources. The USGS also cooperates with State agencies to estimate loads of chloride from road-deicing activities.

\section{Nitrogen Loads From Streams in Connecticut to the Long Island Sound, New York}

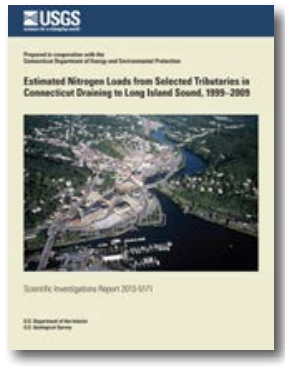

In cooperation with the CTDEEP, the USGS estimated nitrogen loads to Long Island Sound from streams in Connecticut and contributing areas to the north from October 1998 to September 2009. The study included an analysis of status and temporal trends in nitrogen loads. Publication at http://dx.doi.org/10.3133/sir20135171.

\section{Phosphorus Loads in the Assabet River, Massachusetts}

In cooperation with the Massachusetts Department of Environmental Protection (MassDEP) and in support of the requirements of total maximum daily load monitoring for phosphorus, the USGS collected from October 2008 to December 2010 weekly flow-proportional, composite water samples for analysis of concentrations of total phosphorus and orthophosphorus upstream and downstream from each of the Assabet River's two largest impoundments: Hudson and Ben Smith. Waste-

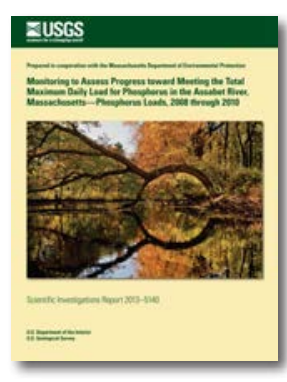
water discharges to the Assabet River contribute substantial amounts of phosphorus, which support accumulations of nuisance aquatic plants that are most evident in the river's impounded reaches during the growing season. Publication at https://pubs.er.usgs.gov/publication/ sir20135140.

\section{Nitrogen and Phosphorus Loads in Lake Champlain}

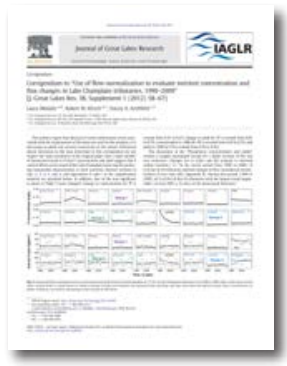

The USGS collaborated with the Vermont Department of Environmental Conservation and the New York State Department of Environmental Conservation to evaluate 20 years of total phosphorus and total nitrogen concentration data for 18 Lake Champlain tributaries using a new statistical method based on weighted regressions to estimate daily concentration and flux histories based on discharge, season, and trend as explanatory variables. Publication at http://dx.doi.org/10.1016/j.jglr.2011.10.002.

\section{Concentrations of Chloride From Road Deicing in Chittenden County, Vt.}

In cooperation with the Vermont Agency of Transportation, the USGS estimated concentrations and loads of chloride from road-deicing activities in three streams in Chittenden County from 2005 to 2007. For this analysis, the LOADEST regression program was used with a model that included two explanatory variables (streamflow and specific conductance). Publication at https://pubs.er.usgs.gov/publication/sir20095236.

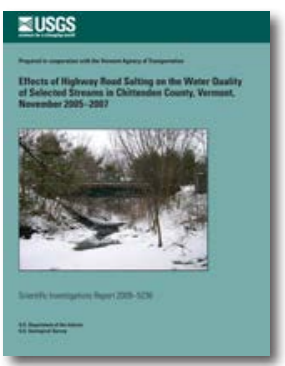




\section{Mercury Studies}

The USGS cooperates with the EPA, the National Park Service (NPS), State agencies, and other organizations to understand the environmental occurrence of various mercury species, to evaluate the potential for toxicity and bioaccumulation, and to assess potential remediation practices. Monitoring and assessing for mercury in the environment can be complex due to the nature of mercury behavior and the low levels in which it occurs; the USGS leads the international and domestic scientific community in the science of mercury in the environment.

\section{Mercury Near a Former Chloralki Facility in Coos County, New Hampshire}

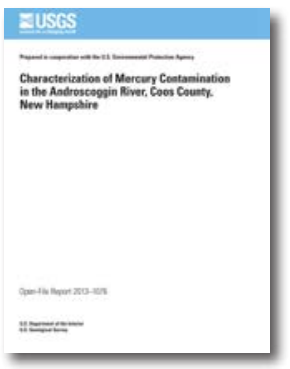

In cooperation with the EPA, the USGS conducted a study to compare surface water, pore water, sediment, and biota total mercury and methyl mercury concentrations upstream and downstream from a former chloralkali facility in Coos County and evaluate the potential for methylation of divalent mercury and mercury bioaccumulation. Publication at https://pubs.er.usgs.gov/publication/ofr20131076.

\section{Mercury Concentrations in Fish and Loon in Lakes}

In collaboration with Ecosystems Research Group, Ltd., the EPA, the Vermont Department of Environmental Conservation, Biodiversity Research Institute, Northeast States for Coordinated Air Use Management, and the New England Interstate Water Pollution Control Commission, the USGS developed the empirical model Mercury Geospatial Assessments for the New England Region (MERGANSER) to predict mercury concentrations in fish and loon tissues in lakes in New England. Publication at http://dx.doi.org/10.1021/es300581p.

\section{Sorbent Reduction of Mercury at Acadia National Park, Maine}

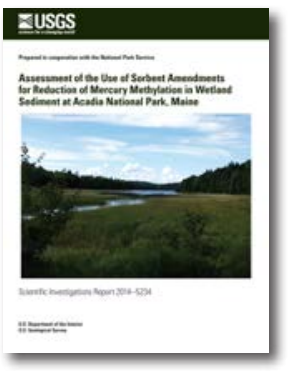

In cooperation with the NPS, the USGS studied the potential use of zero valent iron and granular activated carbon as sorbent amendments for the reduction of mercury methylation in wetland sediments at Acadia National Park. Publication at http://dx.doi.org/10.3133/ sir20145234.

\section{Mercury and Methylmercury in Lake Champlain}

The USGS studied stream water fluxes of total mercury and methylmercury into and out of Lake Champlain from 2001 to 2009. Mercury loads to Lake Champlain were partitioned between particulate and dissolved forms and related to atmospheric deposition. Publication at http://dx.doi.org/10.1016/j.envpol.2011.07.006.

\section{Toxics and Emerging Contaminants}

The USGS cooperates with Indian tribes, the EPA, the Fish and Wildlife Service (FWS), and State agencies to understand the environmental occurrence of toxic substances, including pharmaceutical compounds, wastewater micropollutants, PCBs, pesticides, and coliform bacteria. The USGS is well positioned to provide state-of-the-art science in the field of toxic and emerging contaminants.

\section{Wastewater Micropollutants in Lake Champlain Near Burlington}

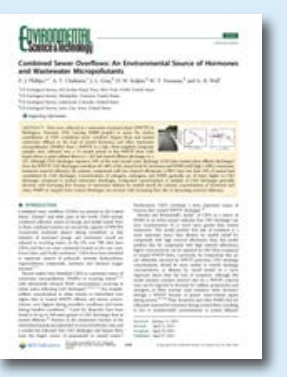

The USGS studied the relative contribution of combined sewer overflow bypass flow and treated wastewater effluent to steroid hormones and other wastewater micropollutants from a wastewater treatment plant to Lake Champlain near Burlington. Contaminant loads were studied in relation to magnitude of runoff and compound-specific removal efficiencies. Publication at http://dx.doi.org/10.1021/ es3001294.

\section{Fecal Coliform Bacterial Contamination in the Meduxnekeag River Near Houlton, Maine}

In cooperation with the Houlton Band of the Maliseet Indians, the USGS conducted a study to identify potential sources of fecal coliform bacterial contamination in the Meduxnekeag River near Houlton. Fecal coliform bacterial contamination was studied in relation to flow conditions, land cover, and potential point sources including a wastewater treatment plant. Publication at http://dx.doi.org/10.3133/sir20135144.

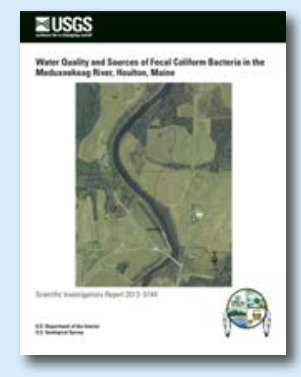

\section{Flora and Fauna of the Penobscot River, Maine}

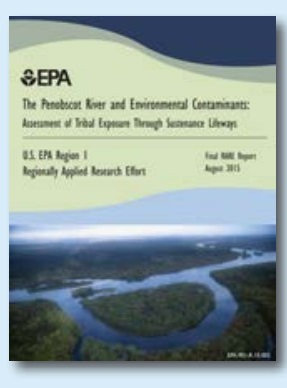

In cooperation with the EPA, the Penobscot Indian Nation, the Agency for Toxic Substances and Disease Registry, and the FWS, the USGS conducted a preliminary contaminant screening of the flora and fauna of the Penobscot River ecosystem. The objectives included field surveys and laboratory analysis on targeted flora and fauna for chemical exposure to dioxins and furans, PCBs, total mercury and methylmercury and surveying surface water, drinking water, and sediment from the Penobscot River and Indian Island in Penobscot County to assess the exposure of tribal members to contaminants based on cultural sustenance practices. Publication at http://www.epa.gov/sites/production/files/2015-12/documents/ final-rare-report-august-2015.pdf.

\section{Pharmaceuticals in the Merrimack River in Lowell, Mass.}

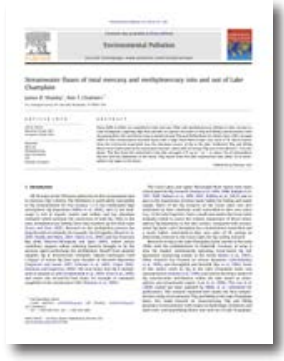

In cooperation with the MassDEP, the USGS studied the occurrence of 14 commonly used human-health pharmaceutical compounds and fecal indicator bacteria in the Merrimack River in Lowell, Mass., in 2008 and 2009. Publication at https://pubs.er.usgs.gov/publication/ sir20115192.

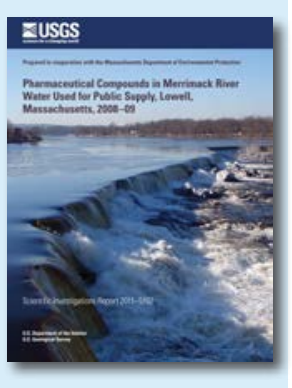




\section{Eutrophication and Nuisance Algal Blooms}

The USGS cooperates with water-resource managers at the EPA and the NPS to study nutrient inputs to estuaries to better understand the process of eutrophication, sources of nutrients and the development of nuisance algal blooms.

\section{Sources of Nutrients to Estuaries in the Northeastern and Mid-Atlantic United States}

In cooperation with the EPA, the USGS investigated nutrient sources to estuaries in the northeastern and mid-Atlantic United States to aid water-resources managers concerned with eutrophication and nutrient management. Spatially referenced regressions on watershed attributes (SPARROW) nutrient models were developed to represent source conditions. Publication at http://dx.doi.org/10.1111/ j.1752-1688.2011.00582.x

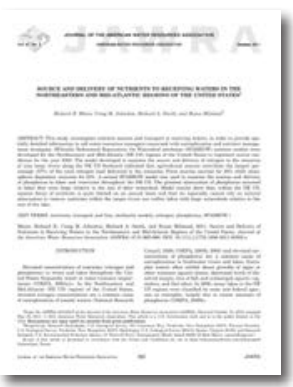

Nitrogen Loads to the Northeast Creek Estuary at Acadia National Park

EUSCS

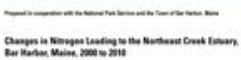

In cooperation with the NPS, the USGS determined trends in nitrogen loading to the Northeast Creek Estuary at Acadia National Park from 1999 to 2011 to assess vulnerability to eutrophication and habitat degradation. Publication at http://dx.doi.org/10.3133/ ofr20131256.

\section{Nutrient Inputs to the Bass Harbor Marsh Estuary, Maine}

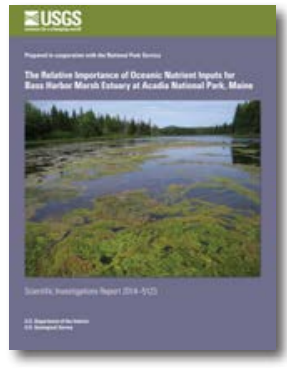

In cooperation with the NPS, the USGS determined the relative importance of nutrient inputs from atmospheric, oceanic, and terrestrial sources to the Bass Harbor Marsh Estuary at Acadia National Park in 2011 and 2012. Eutrophication and nuisance algal blooms are a recurring problem in this estuary. Publication at http://dx.doi.org/10.3133/sir20145123.

\section{Eutrophication on Cape Cod, Mass.}

In cooperation with MassDEP, the USGS studied the effects of wastewater-management actions on the hydrologic system and nitrogen loading rates to ponds, streams, and coastal waters on Cape Cod that are at risk for eutrophication. Publication at https://pubs.er.usgs.gov/ publication/sir20135060.

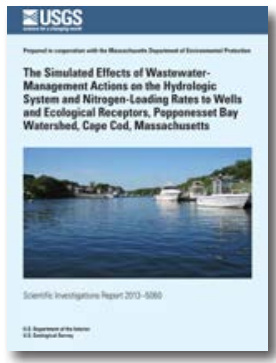

